Andrew Young School of Policy Studies Research Paper Series

Working Paper 06-02

February 2006

Department of Economics

\title{
The Institutional Theory of John R. Commons: Foundation for a Heterodox Labor Economics
}

\author{
Bruce E. Kaufman \\ Georgia State University
}

This paper can be downloaded at:http://aysps.gsu.edu/publications/2006/index.htm

The Social Science Research Network Electronic Paper Collection: http://ssrn.com/abstract=889387 
The Institutional Theory of John R. Commons: Foundation for a Heterodox Labor Economics

\author{
Professor Bruce E. Kaufman \\ Department of Economics \\ Georgia State University \\ Atlanta, GA 30303 \\ USA \\ Email: bkaufman@gsu.edu
}

February 10, 2006 
Abstract: Over the last three decades neoclassical economic theory has become the dominate approach for the study of labor, most clearly in North America but also increasingly in Europe and elsewhere. Rival heterodox approaches, on the other hand, are threatened with marginalization, partly due to the imperializing tendencies of neoclassical economics and partly due to the inability of heterodox economists to articulate an alternative unified theoretical framework. The purpose of this paper is to push forward the heterodox project by outlining a theoretical framework and set of core ideas that may provide the basis for an alterative paradigm. Toward this end, I re-examine the theoretical writings of institutional economist John R. Commons and describe and synthesize his theory of institutional economics. Although his theory is general, I focus on its application to the study of labor. Key concepts are bounded rationality, property rights, working rules, institutions, transactions, and incomplete contracts. I argue that these concepts not only form a coherent body of theory but also give rise to numerous insights and predictions about labor markets and the employment relationship, highlight crucial weaknesses and lacunas in the neoclassical approach, and provide a theoretical framework for an integration of the economic and social dimensions of human behavior.

The Institutional Theory of John R. Commons: Foundation for a

Heterodox Labor Economics

John R. Commons was a founder of the field of labor economics and was the most prominent labor economist of the early twentieth century in North America. He is also widely recognized -- along with Sidney and Beatrice Webb of the United Kingdom -- as a founder of the field of industrial relations. Commons' academic work on specific labor and industrial relations topics, such as trade unions, labor management and labor history, are regarded as pioneering and continue to be cited. Commons is also generally regarded as one of the three founding members of the American institutional school of economics.

What Commons is not remembered for is the development of theory in labor economics, or even in industrial relations (his “extension of markets” hypothesis probably being the closest exception). Indeed, the conventional wisdom among mainstream economists is that Commons and colleagues were largely fact-gathering empiricists who opposed theoretical abstraction and instead practiced an a-theoretic form 
of "descriptive economics" (Boyer and Smith, 2001). Likewise, the conventional verdict on their version of institutional economics is that it lacked any theoretical core and instead devolved into a program of criticism and dissent (Blaug, 1997). Even among favorably-disposed industrial relations scholars, Commons theoretical writings are rarely cited and no theory of industrial relations has been built upon them.

The idea that Commons was not interested in economic theory, and did not try to develop theory, is demonstrably false - at least if "theory" is interpreted more broadly than of the orthodox kind. His first book, The Distribution of Wealth (1893), was entirely a work of economic theory, and he devoted the last twenty-five years of his life to writing three other theoretical treatises: The Legal Foundations of Capitalism (LFC, 1924), Institutional Economics: Its Place in Political Economy (IE, 1934), and The Economics of Collective Action (ECA, 1950). In the Preface to LFC Commons states, "This work is primarily theoretical" and in the first paragraph of $I E$, he uses the term "theory" (or "theories") three times in motivating the purpose and subject of the book.

What is a fair matter of debate is whether Commons was successful at developing theory. If a discernible intellectual or citation "footprint" in modern economics is used as the criteria, the judgment can only be a resounding "no.” Even his admirers (e.g., Ramstad, 1995) conclude Commons has had next-to-no influence on the body of economic theory and, in industrial relations, the few scholars that cite his theoretical works limit themselves to selective quotations (Barbash, 1976, is a partial exception).

One reason Commons' theoretical work has borne so little fruit is that it is extremely difficult to understand. His books and articles on labor topics are reasonably transparent but in his theoretical works the writing style is exceedingly dense, the 
exposition of ideas cumbersome and unsystematic, and the terminology for key concepts often ill-defined and foreign to economists. Frank Knight (1935: 805), one of America’s most able economists of that era, stated in his review of $I E$, "The reviewer, after going through the book, could not give a statement of the author's 'theory' .... [even though] I have expended much honest effort.... in trying to make out what Professor Commons means.” In a similar but modestly more positive vein, Boulding (1957, p. 8) characterized Commons' theoretical works as a "tangled jungle of profound insights."

The contributions of this paper are in two principal areas. First, I endeavor to summarize in simple and transparent prose the major ideas and overall framework of Commons' theory of institutional economics. Several other people have also done this (e.g., Parsons, 1950; Chamberlain, 1963; Gonce, 1966; Rutherford, 1983; Whalen, 1989; Ramstad, 1990; Hodgson, 2003), but my account is nonetheless distinctive for several reasons. In particular, I outline Commons' theory in a way that has more obvious links and contrasts to neoclassical theory and derive new ideas, interpretations and implications from this theory. Further, I also highlight theoretical and methodological linkages between the "old institutional economics" (OIE) of Commons and the two related fields of economic sociology (ES) and "new institutional economics" (NIE). Although scholars in both fields (e.g., Williamson, 1985; Granovetter, 1991; Streeck, 2005) recognize this linkage, it remains obscure and under-developed. Thus, this paper demonstrates that concepts central to economic sociology, such as bounded rationality, power, institutions, and social structure, are embedded as core parts of Commons' institutional economics. And, lastly, to the best of my knowledge this paper is the first presentation of Commons' theoretical framework with direct application to labor and employment issues. Labor and 
employment are examined partly because this was Commons’ major area of applied research, partly to provide greater focus to the discussion of theory and implications, and partly because - as Marx maintained - the wage relation is arguably the most important social relation in capitalism.

The sine qua non of a theory is that it explains or predicts important features of an economy and economic behavior. This paper's second contribution is to demonstrate that Commons' institutional economics qualifies as a theory in this sense; indeed, I argue it may well provide the basis for an alternative heterodox economic paradigm. To do so, throughout the paper I use Common’s ideas to explain, albeit with brevity due to space constraints, numerous features and outcomes of labor markets and the employment relationship, as well as omissions and inconsistencies in neoclassical theory. In this regard, I argue that in some areas institutional economics and neoclassical economics are theoretical complements in that they theorize different dimensions or objects in an economy or take different variables as endogenous and exogenous, while in other areas they are substitutes in that they consider the same objects/behaviors and give different answers/predictions.

Preliminaries: Defining Key Terms

A fruitful discussion is promoted by explicitly defining several key terms that are used throughout the paper.

The first is neoclassical economics. This term means different things to different people, so a common benchmark is helpful. According to The MIT Dictionary of Economics (Pearce, 1999, p. 301), neoclassical economics is the following: 
"A body of economic theory which uses the general approach, methods, and techniques of the original nineteenth century marginalist economists... In particular, they studied the possibility of a set of market prices which ensured the equality of supply and demand in all markets. The idea of a perfectly competitive economy in equilibrium, which may be attributed especially to Walras, is central the neo-classical scheme."

The definition offered by Boyer and Smith (2001) in their recent article on the neoclassical tradition in labor economics is broadly in this spirit. They state (p. 212), "Neoclassical theory [is] a sparse model of maximizing behavior in the face of competition and constraints.” They more clearly highlight that a key part of neoclassical economics is the axiom of rational behavior, represented analytically by the technique of constrained maximization, and then follow the MIT Dictionary definition by also emphasizing the second key component, highly competitive markets. The idea that highly competitive markets are central to neoclassical economics is further affirmed by Kniesner and Goldsmith (1987, p. 1241) who state, "The auction-market analysis of prices and quantities is the core of neoclassical economics.” This auction market model of the economy is the one pioneered by Walras, and in what follows I refer to it as the "core" or Walrasian version of neoclassical economics.

Of course, neoclassical economists also recognize that many markets are not, in a literal sense, perfectly competitive and they have endeavored over the years to broaden the paradigm to incorporate a variety of human and market imperfections. Given these amendments, the paradigm is still anchored around its most celebrated and fundamental 
insight - the InvisibleHand Theorem. That is, neoclassical economics takes as its fundamental proposition Adam Smith's assertion that self-interest and competition, operating through a system of decentralized and largely unregulated markets, maximizes efficiency and social welfare. In this spirit, Edward Lazear (2000) declares (p. 101-102), “Adam Smith’s concept of the invisible hand is a guiding principle in [neoclassical] economics.... More formal statements [demonstrate].... the idea that competitive equilibrium is efficient," while Melvin Reder (1982, p. 11) asserts the central premise of the Chicago School of economics (the most famous promoter/defender of neoclassical economics) is "the hypothesis that decision makers so allocate the resources under their control that there is no alternative allocation such that any one decision maker could have his expected utility increased without a reduction occurring in the expected utility of at least one other decision maker." Thus, as used in this paper "neoclassical economics" recognizes the existence of human and market imperfections but nonetheless presumes that these imperfections are sufficiently spotty and small that the Invisible Hand Theorem is empirically valid as a first approximation and a market economy can be modeled "as if" it is (mostly) competitive.

The next key term is institutional economics. According to the MIT Dictionary, institutional economics is "A type of economic analysis which emphasizes the role of social, political, and economic organizations in determining economic events.... The emphasis on the role of institutions is a criticism of conventional economics which may be said to ignore the non-economic environment in which individuals make decisions.” This definition broadly accords with the statement of Warren Samuels (1969), a leading interpreter and expositor of institutional economics, that (pp. 68, 69) "Institutionalists 
concentrate upon the basic problem of the organization of the economy as a system, including the market.... Institutional economics concerns itself with, first, the working rules governing the distribution and redistribution of power and which are in various ways involved with both psychology and knowledge as bases of social action, and, second, with the interrelation of legal and economic processes as a fundamental vehicle to comprehend the basic organizational problem in modern society.”

All of these facets of institutional economics will be examined in far greater detail in what follows, so I eschew further elaboration here. Where additional clarification is needed at this point, however, concerns divisions within institutional economics and the place of Commons therein. It is common, for example, to distinguish between the old institutional economics and the new institutional economics (Furubotn and Richter, 1997; Rutherford, 2001). Commons was part of the OIE and is considered one of its three founders, along with Thorstein Veblen and Wesley Mitchell. Although the economics of these three people are united by certain common principles, there is also considerable diversity. Hence, within the OIE are different branches, such as the Texas School (Clarence Ayres and followers of Veblen) and the Wisconsin School that follows Commons. The institutional economics described in this paper follows the latter but also shares important elements with the former. Then there is the NIE, which grew out of the work of Ronald Coase, Oliver Williamson and others. Some NIE (and OIE) economists claim the "old" and "new" branches of the field are largely separate and incommensurable (e.g., Ramstad, 1996; Aoki, 2001), and in earlier years a number of writers from both camps took pains to disassociate their work from the other. More recently, however, writers from both the OIE and NIE have argued that the two research 
programs share a number of important common points and are thus both part of the same intellectual paradigm, broadly conceived (e.g., Medema, 1996; Furubotn, 1997). I not only subscribe to the latter view but endeavor to advance it (Kaufman, 2004b).

Commons’ Institutional Economics: Historical Development and Relation to Orthodoxy Most contemporary scholars are unfamiliar with Commons' theoretical work and, more generally, the old institutional economics. Thus, appreciation of Commons' theory is greatly aided by first putting it in historical context and juxtaposition to orthodox theory.

The place to begin is to note that, according to Commons, institutional and neoclassical economics grow out of the same root and have significant overlap (Biddle, 1991). The beginning economics text for both paradigms is Adam Smith's Wealth of Nations (1776/1937). Commons states, for example, that "I would begin teaching the science of economics with Adam Smith” (1934c, p. 1) and that institutional economics is a "return to the true spirit of Adam Smith" (LFC, p. 363), while speaking of neoclassical economics he remarks (p. 362), “Adam Smith started with a view of the forest but his followers lost themselves in the woods." The "true spirit” of Adam Smith, according to Commons, is to take a broad "political economy" perspective on economic science, the “forest” that Smith correctly saw (but which in Commons’ view he under-emphasized) was the importance of institutions in the form of a "well governed society" (Smith, p. 11) to the successful operation of an economy, and the "woods” that Smith’s followers became lost in was the tendency to take as a "given" the economy's social relations and institutional framework and examine in ever-finer detail the logic of market exchange. 
After Smith the two paradigms diverged and followed different paths. The seminal figures were Malthus and Ricardo in the early 1800s and their contrasting methods and theories. According to Commons ( $L F C, 4, I E$, p. 846), the path that led to institutional economics originated with Malthus, while the path to neoclassical economics came from Ricardo. The key features of Malthus' economics are an emphasis on imperfect human rationality, the role of institutions (e.g., the church, family, state) in regulating individual behavior, the use of empirically-informed premises in theoryconstruction, denial of Says Law and the proposition that markets are self-regulating, and a policy position open to government regulation of markets in order to balance and protect the interests of workers vis a vis consumers (as in the Corn Law debates). Ricardo's economics, on the other hand, was highly abstract and deductively derived from a few a priori canonical assumptions, gave a scant role to institutions in the economic process, supported free trade and the self-regulating nature of markets, and took a strong stance against government interference in markets.

Commons then traces the evolution of institutional economics though a long and varied list of heterodox economists, such as Henry Carey, Karl Marx, the British and German historical/social economists (e.g., Gustav Schmoller, Sidney and Beatrice Webb), John Hobson and Thorstein Veblen, as well as the legal doctrines of lawyers and the Supreme Court and the writings of various scholars in biology, sociology, psychology and political science, such as Charles Darwin, Emile Durkheim, Max Weber, and William James. John M. Keynes is also in the institutional (heterodox) camp, broadly considered, in that he traced his macroeconomic theory to Malthus and Hobson, claimed that a market economy is not self-regulating, and rested part of his theory on human 
emotions, imperfect rationality, and missing/imperfect institutions (Keynes, 1936;

Atkinson and Oleson, 1998). Illustrative of the close intellectual kinship between Keynesian and institutional economics, Keynes wrote a personal letter to Commons in 1927 and declared (Skidelsky, 1992, p. 229), “There seems to be no other economist with whose general way of thinking I feel myself in such genuine accord.”

Neoclassical economics, as it developed from Ricardo, went in a different direction. Some writers in the classical/neoclassical line, such as Mill and Marshall, endeavored to incorporate one or more heterodox elements, such as the historical method or importance of institutions. The main current of $20^{\text {th }}$ century neoclassical economics, however, as represented in classics works such as Hicks’ Value and Capital (1939), Samuelson's Foundations of Economic Analysis (1947) and the general equilibrium theory of Arrow-Debreu (1954), instead followed Leon Walrás and actively sought to minimize or exclude these considerations.

Illustratively, in Elements of Pure Economics (1874) Walrás distinguishes three branches of economic behavior: industry (production), exchange, and institutions. He states that industry falls outside of economics as a science, since it largely represents an “art” (e.g., the practice of management), while institutions are also disqualified since they involve ethical considerations of right and wrong (e.g., as in the creation of law). The residual subject is exchange which Walrás argues is best understood using highly competitive markets as the model, such as the Paris stock exchange. Thus, he tells readers “this pure theory of economics is a science which resembles the physico-mathematical sciences in every respect” (p. 71) and "Our task then is to discover the laws to which these purchases and sales tend to conform automatically. To this end, we shall suppose 
that the market is perfectly competitive, just as in pure mechanics we suppose, to start with, that machines are perfectly frictionless” (p. 84). In the remainder of the book Walrás develops the mathematical model of general equilibrium.

Several observations are worth noting. First, the Walrasian (core) version of neoclassical economics is, in a substantive sense, both institutionally empty and institutionally neutral. It is empty because institutions either do not exist (e.g., money has no theoretical role, firms are technologically-determined production sets) or are passive and exogenously given background factors, such as zero-cost perfectly competitive markets, a seamless web of contract law, perfectly divisible and well-defined set of property rights, and a government that perfectly enforces them. It is also institutionally neutral in that the predicted outcomes are independent of both property rights assignments (stated by the Coase theorem) and the form of ownership, such as whether property is owned by the state in a Lange-Lerner model of socialist general equilibrium or privately owned in an Arrow-Debreu model or, alternatively, whether capital hires labor or labor hires capital (Furubotn and Richter, 1997). Second, other important considerations, such as the distribution of endowments and income, are also taken as exogenous "givens” and, more importantly, are also neutral in that no matter what the initial endowment the economy still yields a Pareto optimal set of outputs (as stated in the Fundamental Welfare Theorems). Third, people are reduced to individualistic, hyperrational “social atoms” (utility functions are independent, people have super-computers for brains) whose behavior is unaffected by social rules and norms and respond in a passive way to market forces, while labor is modeled as a commodity - albeit one with a utility function - that differs in no fundamental respect from the other $\mathrm{X}_{\mathrm{i}}$ factor inputs 
(Prasch, 2004; Swedberg, 2005). And, fourth, the entire system is "mechanistic" in that once the assumptions and initial conditions are given the outcome is both logically preordained and determined by an unseen force (the invisible hand) that efficiently coordinates the action of individuals similar to the way gravity coordinates the sun and planets (Mirowski, 1989).

The position taken by Commons, if not all institutional economists, is that the Walrasian model, and neoclassical paradigm in general, are useful and insightful for certain purposes, situations, and questions. Nowhere, for example, does Commons reject marginal analysis or calculus-based mathematics (indeed, he used marginal analysis extensively in The Distribution of Wealth); rather, his contention is that in some areas of economic analysis these tools are inapplicable due to the indivisible, discrete, pathdependent, or non-quantifiable nature of the economic phenomena. Going further, Commons' general position is that institutional economics and neoclassical economics are complements and that the former should build on the useful insights and theories of the latter. Thus, he states that "physical sciences have been developed into highly mathematical or quantitative expressions, and economic science may learn from their important methods of inquiry" (Commons, 1925, p. 6) and "Institutional economics, therefore, cannot separate itself from the marvelous discoveries and insights of the pioneer classical and psychological [marginal utility] economists” (IE, p. 69). Speaking specifically with regard to labor economics, he (1919, p. 17) states “The commodity theory of labor .... is not false, it is incomplete.”

Rather than replacing orthodox economics, Commons claims that the role of institutional economics is to give attention to those factors omitted from or taken as a 
given in traditional theory. Thus, in IE (pp. 5-6) he states, "The problem now is not to create a different kind of economics - 'institutional' economics - divorced from preceding schools, but how to give to collective action, in all its varieties, its due place throughout economic theory. In my judgment, this collective control of individual transactions is the contribution of institutional economics to the whole of a rounded-out theory of Political Economy." As this quote indicates, what Commons claims is the core of institutional economics is the role of collective action and collective control, as exercised through society's network of institutions in the form of governments, business firms, trade unions, families, churches, social norms, etc., in shaping and regulating the individual action that is the core focus of neoclassical economics. Illustratively, he states "The law of supply and demand is inevitable .... and, like death or the law of gravity, cannot be avoided" (IE, p. 101). Yet the job of institutional economics is to "analyze the forces and personifications [i.e., institutions and human beings] behind supply and demand" (p. 75). Seen in this light, Commons is simply trying to bring back into economic theory as active variables what Walrás, Hicks, Samuelson, and Arrow-Debreu omit or hold in deep background. It is for this reason that institutional economics may be considered a heterodox form of general equilibrium theory (i.e., a theory of how institutions coordinate, reconcile and satisfy the conflicting desires of individuals) and why it has close intellectual kinship to historical economics, economic sociology, and legal economics.

At another level, however, institutional and neoclassical economics are more clearly substitutes and rivals. Core features of neoclassical economics are methodological individualism, a deductive and a priori approach to theory building, the models of 
economic man (rational actor model) and competitive markets, and the Pareto welfare goal of maximum efficiency in resource use. These principles lead to a body of theory that is highly individualized, reductionist, a-historical, formalized, universalistic, deterministic, divorced from ethical considerations of fairness and social justice, protective of both the interests of consumers over workers and the status quo in the distribution of social wealth, and opposed to most forms of market regulation. As emphasized in more detail shortly, the key properties of neoclassical theory are an economy of zero frictions and complete contracts.

Institutional economics goes in a different direction. It treats the economy not as a natural science mechanism but as a social science organism, blends methodological individualism and methodological holism (e.g., the idea that institutions are more than the sum of individual members and have independent existence), endeavors to build theory using a realist/empirically-grounded form of adductive reasoning (adducing cause-effect relationships from empirically informed priors), uses analytical tools such as comparative institutional analysis, game theory, computer simulations and prose, seeks to develop a behavioral/social model of the human agent, introduces other modes of resource allocation/coordination besides markets and price (e.g., firms and command), assumes most markets are imperfectly competitive, and judges economic performance by an expanded welfare function that gives explicit weight to efficiency, equity, and human self-development (Ramstad, 1986; Jacoby, 1990; Kaufman, 2004a). The resulting theory gives a "socialized” view of economic behavior; is multidisciplinary, evolutionary, historically and culturally contingent, and more difficult to analytically represent; contains indeterminateness at key places; and provides space for a positive role for 
institutional intervention in the economy and social reform. All of these features are also part of theorizing in the modern field of economic sociology (Smelser and Swedberg, 2005), while at the same time Commons gives more emphasis to the formal rules and institutions surrounding markets than does economic sociology (Streeck, 2005).

In terms of policy, Commons version of institutional economics leads to the conclusion that capitalism is the best available economic system, since it promotes efficiency, innovation, and personal liberty better than alternative systems, but nonetheless is subject to significant market imperfections, coordination failures, and forms of social injustice that collectively lead to waste, inefficiency, and inequity. It was for these reasons that Commons (1934b, p. 143) described his life work as an institutional economist as an effort to "save capitalism by making it good;" a project that required him to develop an alternative economic paradigm to support and legitimize social reform (e.g., the New Deal and development of the modern welfare state) given the status quo, laissez-faire, and pro-consumer/anti-producer slant of orthodox theory (Thurow, 1988; Jospeh Stiglitz, 2000, p. 3, who bitingly remarks on this matter "it might seem as if the fundamental propositions of neoclassical economics were designed to undermine the rights and position of labor.”) Thus, in institutional economics the invisible hand of free markets must be supplemented and sometimes replaced by the visible hand of coordination and reform by the state and other institutions, leading to what Commons calls a "managed equilibrium” (IE, p. 120) and in more recent times forms of “coordinated capitalism” (Streeck and Yamamura, 2001). The necessity of a managed equilibrium, in turn, arises from two key assumptions in institutional economics: an economy of positive frictions and incomplete contracts. 
Viewed in this manner, neoclassical and institutional economics are substitute paradigms in that their specific methods and theories are largely opposites. In this respect, Douglas North $(1984$, p. 7) states that neoclassical economics "ignores the costs of trade" and thus "is really half a theory.” Institutional economics incorporates the costs of trade and thus provides the other half. Yet, broadly viewed, they are also complements in that each explores different dimensions of the economic problem and highlights different aspects of economic behavior. Given this duality, I turn to a more detailed exposition of Commons’ theory of institutional economics.

\section{An Outline of Commons’ Institutional Theory}

I now proceed to a more detailed explanation of the major parts of Common's theory of institutional economics. His theory has both a microeconomics and macroeconomics component, but the former is the more fundamental and is focused on here. Where possible, I also endeavor to indicate linkages between Commons, Keynes, and ES and NIE.

Commons states that the science of economics "deals with the problems of mankind as they go about trying to make a living or to get rich. Thus the economists are interested primarily in the problems which arise from the production of wealth and the distribution of income" (ECA, 21). This conception views economics as a study of the formation and operation of an economy, where an "economy" is a system of people and institutions that provision society with goods and services. -- a view parallel to that of Coase (1994, p. 41) who states that economics studies "the working of the social institutions which bind together the economic system.” It partially incorporates but 
remains significantly different in scope from the conception of Lionel Robbins, Gary Becker and other neoclassical economists that economics is the study of how to efficiently allocate scarce resources (i.e., the best means to a given end). The Commons/Coase conception, it may be noted, appears closer to the viewpoint of Adam Smith, who states that political economy can be "considered as a branch of the science of a statesman or legislator” [i.e., how to construct an economy using legal rules and institutions] with the purpose of discovering methods that "enrich both the people and the sovereign” (p. 397).

As with Smith and practically all economists, Commons (IE, p. 6) claims that the starting point for a theory of economics is the condition of scarcity. The core Walrasian version of neoclassical economics proceeds to analyze how people overcome scarcity through the operation of the invisible hand in competitive markets. Commons central point, and the starting-off place for institutional economics, is the observation that the assumptions made in this theory take for granted or assume away many of the most problematic and difficult parts of the actual operation of an economy. In particular, Walrasian theory assumes that there exist perfectly defined property rights, perfectly enforced contract law, pre-existing and zero cost markets and other supporting institutional infrastructure, and perfect information and perfectly rational people. The combination of perfect people in perfect markets inevitably leads to the best of all possible outcomes, as enshrined in the Invisible Hand Theorem, and a negative verdict on all interferences with market processes. As earlier stated, Commons accepts this theory as providing certain useful insights and implications, particularly of a conceptual and longrun nature. But he also maintains that this theory has only small relevance to 
understanding the actual operation of economies, particularly in the short-to-medium run, because it omits all the imperfections and frictions that are endemic to any human endeavor. Thus, what is required is an alternative economic theory that takes as a baseline the operation of the economy with imperfect people in imperfect markets regulated by imperfect governments. As Coase (1994, p. 18) puts it, "realism in assumptions forces us to analyze the world that exists, not some imaginary world that does not,” and in a similar vein Steven Cheung (1988, p. 516) states, "Transaction-cost economics is realworld economics.”

Institutions. In this spirit, Commons (IE, p. 4) claims that the three fundamental challenges facing humankind in overcoming scarcity are resolving conflict, dealing with interdependence, and creating civic order. That is, in an imperfect world with material scarcity people inevitably come into conflict over control and use of resources, opening the possibility that theft, predation and violence displace mutual-gain production and exchange (i.e., that "take" displaces "make" and "buy”). Likewise, an economy requires that people work together, cooperate and respect each other's property and personal rights, yet distrust, opportunism and fraud can quickly undermine these things. And, finally, an economy requires a transparent, honest, and strong government that impartially administers the laws and effectively maintains civic order, yet governments are easily corrupted, the laws subverted to enrich special interests, and lawlessness and criminality allowed to run rampant.

Walrasian economic theory obviates these problems by the assumptions it makes, but in Commons' institutional economics - and economic sociology in the tradition of Durkheim and Weber -- they are the key issues that must be resolved for 
successful production and exchange to take place. But how are the problems of conflict, interdependence and order to be solved? According to Commons, the answer is humanmade institutions.

An institution, as defined by Commons, is a particular regime or body of working rules. Others have framed this idea as "rules of the game" and "regimes (or modes) of regulation” (Furubotn and Richter, 1997; Boyer and Saillard, 2002). In particular, he defines an institution as, "collective action in control, liberation, and expansion of individual action” (ECA, p. 21). Examples of working rules are laws, court decisions, corporate charters, business firms' human resource policies, trade union constitutions and collective bargaining contracts, social norms and cultural conventions, religious doctrines, ethical principles, and custom. Every human-made entity or organization, called a going concern by Commons, is governed by a body of explicit and implicit working rules and its behavior and performance are guided and structured by these rules. This idea is carried forward into the NIE by Williamson (1985) who labels the working rules the governance structure of economic organizations (p. 15). The importance of working rules goes beyond formal organizations, however, for they structure and regulate all forms of ongoing social behavior between human beings. In other words, human interaction is always and everywhere "instituted" -- or "socially constructed” (Granovetter, 1991, p. 76).

Commons proceeds to note that all of these working rules, both formal and informal, establish property rights (or simply "rights") in the sense that they give individuals control over scarce resources. Property (ownership) rights, he says, are "rights to scarcity" (ECA, p. 165) and define "all the activities which individuals and the 
community are at liberty or required to do or not do, with reference to the object claimed as property” (IE, p. 74). Importantly, the object claimed as property may be not only a material object but also a financial instrument (stock, bond, etc.) or intangible item, such as a claim to a job, access to a market, a political liberty, a human right, or a social convention (e.g., the right to be treated with respect). Commons (ECA, p. 21) states that "In modern capitalism the most important stabilized economic relations are those of private property" and for this reason "ownership becomes the foundation of institutional economics” (IE, p. 5).

The focus on property rights and ownership in institutional economics differentiates it from the traditional price theory version of neoclassical economics. In the latter, for example, property rights and ownership are taken as a given and then the theorist works-out how the process of production and exchange, operating through the laws of supply and demand, determine prices, outputs, and the allocation of resources and income. Commons says (IE:56-57), for example, "It was assumed that all commodities were owned, but the ownership was identical with the physical thing owned, and therefore was overlooked as something to be taken for granted. The theories were worked out as physical materials, omitting property rights.” Thus, in the neoclassical theory of his day demand was derived from the behavior of marginal utility as people consume additional physical units of a good; supply was derived from the behavior of marginal cost as additional physical units of factor inputs are added to production, and a market equilibrium is reached when price balances demand and supply. Property rights and the political sovereignty of the state are omitted as active explanatory variables and all 
economic relations in competitive markets are relations between individuals and things (i.e., human independence rather than interdependence).

Institutional economics, on the other hand, is inevitably political economy because it focuses on the nexus between law and economics, the central role of the state in forming and enforcing the legal regime, and how the politically determined rules of the game affect economic behavior and performance (and vice versa). In this respect it is complementary to James Buchanan’s concept of “constitutional economics” (Vanberg, 1997), the French school of régulation theory (Boyer and Saillard, 2002), and the German school of ordo-liberalism (Grossekettler, 1989). Since economics and law are inextricably intertwined, institutional economics at both a positive and normative level is also a study of ethical economy since law is inescapably based on considerations of intent, justice, and right and wrong and effectively regulates economic behavior only to the extent participants maintain an ethical commitment to observe the rules of the game. And furthermore, institutional economics is also a study of evolutionary economy since the corpus of working rules that structures the economy and molds individual preferences continuously changes over time (Biddle, 1997; Hodgson, 1999). The change in the rules, in turn, is guided by human purpose, thus in Commons' view making economic evolution a process of "artificial selection" rather than the "natural selection" and an ongoing process of "cumulative causation" as attainment of one set of ends gives rise to a new set. Given the focus on rules, power (i.e., ability to satisfy one’s preferences) is also a central construct in institutional economics, as it is in economic sociology (Dobbin, 2005). Power, for example, is exercised by some person(s) when they create and enforce the working rules, and power is also exercised by the people who participate in selecting 
these leaders. The working rules furthermore define each economic agent's opportunity set, endowments, and rights and conditions for exchange of property, thus effectively determining their relative bargaining power and resulting income and command over goods and people. Ultimately, therefore, it is political power, not the impersonal forces of supply and demand, that determines whose interests count in the economy and who reaps the rewards and bears the costs of economic activity (Samuels and Medema, 1997; Schmid, 1987). While political government possesses the ultimate power in society, many other groups and organizations also possess a measure of sovereignty and hence create and enforce their own working rules. Commons (ECA, p. 74) speaks of a "hierarchy of governments," such as business firms, labor organizations, churches, and families. Also included are "invisible" institutions, such as custom and culture. These institutions enforce their rules through a mix of physical, economic, and moral sanctions, such as imprisonment, loss of job, excommunication, and feelings of shame. A firm, therefore, is not only a production function but also a political governance system that invests certain people (the "boss”) with power over others, gives certain people but not others (e.g., shareholders but not workers) the right to choose new leaders, and establishes working rules that distribute economic opportunity and bargaining power (e.g., rules governing job assignment and promotion, employment-at-will versus just cause dismissal).

In one respect, institutional economics simply seeks to highlight and flesh-out the institutional "superstructure" of rules and property rights that create the choice sets and incentives that Walrás and other neoclassical economists tend to treat in a highly simplified and a priori manner. In doing so, institutional economics usefully calls 
attention to the fact that ownership (property rights) is antecedent to all else in determining how an economy performs. Thus, the very existence of a market economy depends on whether the state permits private property, while the existence and size of firms likewise depends (in part) on rights of ownership and costs of transferring ownership. Going further, every significant theoretical construct in orthodox economics, including commodities, utility functions, production functions, efficiency, demand and supply curves, and market price, are not well-defined or operable unless and until there is a well-defined set of property rights. It is entirely appropriate, therefore, to talk of an “institutional theory of price," for price cannot exist without the supporting infrastructure of institutions, and price only takes the value it does given the specific regime of working rules. Likewise, economic policy is always and everywhere "institutional" since it necessarily involves expanding some people's rights and curtailing the rights of others (Samuels and Medema, 1997).

The focus on ownership and property rights does more, however, than simply highlight factors neoclassical economics has historically neglected or taken as a given. In certain respects, economic theory and its conclusions are fundamentally changed. This is revealed by taking a deeper look at core processes of choice, production, and exchange that form the heart of economics.

Choice and the Human Agent. Two intellectual propositions have been most central to institutional economics: first, the claim that the neoclassical "model of man" is defective and should be replaced and, second, that “institutions matter" in determining economic outcomes. The first of these has earned institutional economics a reputation for dissent and criticism, epitomized by Veblen’s (1898, p. 389) satirical critique of 
economic man as a "lightning calculator of pleasures and pains." Satire and realism aside, it is the case that purely based on theory and logic rejection of the economic man model is a necessary condition for the validity of the second proposition - that institutions matter. Hence, I turn to consideration of the human agent and the process of choice. The process of choice is fundamental to institutional economics. Commons observes that in a world of scarcity people must choose one course of action over another and decide how vigorously to pursue it. He states that this choice process is "the allinclusive foundation of modern economics” (ECA, p. 39). Thus, both institutional and neoclassical economics have a theory of choice, entailing in turn a model of the human agent. But the specific aspects of this theory of choice and model of the human agent are where the two paradigms diverge.

The model of the human agent used in neoclassical economics is the rational actor model (“economic man”). Operationally, the rational actor model means the constrained maximization of a well-ordered preference function. Its key properties are (among others) maximization, transitivity, completeness, and continuity. Importantly, all of these assumptions take the form of a priori assumptions posited by economic theorists and are not developed or justified with respect to theories or evidence from psychology. Indeed, Samuelson (1947) declares the desired goal is to as much as possible take psychology out of economics.

The methodology of institutional economics (particularly the OIE version) is different. Institutionalists practice deductive reasoning, but believe the power of deductive reasoning is enhanced when it proceeds from empirically informed priors. With regard to the model of the human agent, an adductive methodology means that 
institutionalists seek to develop a model of the human agent that is informed by the theories and evidence from the behavioral sciences (psychology, sociology, anthropology). Coase (1984, p. 231) framed the challenge as "start[ing] with man as he is.” This area of inquiry is now known as behavioral economics, and is also the approach advocated in economic sociology (Smelser and Swedberg, 2005).

Like Walrás, and also drawing from the legal literature, Commons talks about human behavior and choice in terms of the "human will.” Where he differs from Walrás is in the specific model of the human will. From Commons’ perspective, Walrás removes the human will from economic theory as an active element since it mechanically reacts to changes in external stimuli (e.g., changes in budget constraints), thus making economics akin to physics. The fact that economic man also knows the relevant information set (at least in probabilistic terms) and can calculate optimal solutions is also central to deriving equilibrium outcomes. Commons' strategy is to accept certain parts of the neoclassical human agent but then revise and add to them in ways that are more congruent with theory and research in social psychology. The result is to shift economic theory from a closed to an open system model, replace static equilibrium with dynamic process, and introduce behavioral elements that lead to allocative inefficiency and macroeconomic coordination failures. Out of this conjunction of events is born, in turn, the need for institutions to supplement and supplant the market.

Parts of the orthodox model Commons accepts, at a broad level, are maximization, utility, self-interest, and rationality. He defines utility, for example, as "the satisfaction a person gets in using a thing” (LFC, p. 20) and then says regarding maximization "Each transaction is economic in that each individual is endeavoring to 
make the largest possible use, for his own purposes, of his limited resources” (LFC, p. 129). Of firms he states (IE, p. 526) "the sole motive which dominates them is profit." With respect to self-interest, Commons (IE, p. 799) remarks, "We may assume, with Adam Smith, that everybody seeks his own self-interest, regardless of the effects on others, in all his economic activities....This consists of getting as much gain as possible and suffering as little loss as possible.” And part of what competition and capitalism force people to do is engage in "purposeful thinking” (LFC, p. 360), which can be regarded as synonymous with rationality.

Now come the differences. While Commons accepts the utility construct, he endeavors to give it psychological content. Thus, while utility in orthodox economics is a disembodied ordinal preference relation, for Commons (LFC, p. 20) utility is a "feeling" and therefore an experienced emotional state such as happiness, satisfaction, or subjective wellbeing. In today’s terminology, the neoclassical version is “decision utility” and the institutional version is “experience utility” (Kahneman, Wakker, and Sarin, 1997).

Treating utility as equivalent to (say) happiness leads to a number of implications and predictions absent from orthodox theory (Kaufman, 1999a). For example, the empirical literature in psychology finds that happiness is fundamentally tied to interpersonal (relative) comparisons. This suggests utility functions should be modeled as interdependent, preference relations are "social," and behavior is affected by fairness, envy, and other emotions engendered by comparisons with others. Status-seeking and “keeping up with the Jones,” for example, was highlighted by Veblen (1899) as a key driver of behavior and the capitalist system. Thus, while neoclassical economists tend to dismiss institutional concepts such as “conspicuous consumption,” “fair wages,” and 
"orbits of coercive comparison" as ad hoc because they do not fit into their individualist model of man, from an institutional point of view these are entirely logical and wellfounded concepts and it is the neoclassical version that is substantively mis-specified (Solow, 1990). Likewise, while neoclassical economists typically assume preferences are exogenously given and either uniformly or randomly distributed, Commons argues that people have "institutionalized minds," meaning that preferences are endogenously shaped by their environment (e.g., culture, advertising, etc.) and vary in systematic ways across social classes and groups (Hodgson, 2003; Weber and Dawes, 2005).

While Commons accepts the general principle of maximization, it also needs qualification. For example, constrained maximization is impossible to analytically carryout or realistically practice in the face of fundamental uncertainty (i.e., when even probability distributions are unknown). Thus, when fundamental uncertainty bulks large or significant in economic choice, it may be better scientific method to model decision making using an approximation procedure, such as a convention, trial and error, rule of thumb, or some form of satisficing procedure (Nelson and Winter, 1982; Gigerenzer and Selten, 2001). Likewise, while Commons appears (in the quote above) to give blanket endorsement to the neoclassical proposition that firms solely maximize profits, his support is actually circumscribed because he early-on (Commons, 1919, pp. 47-8) recognized and discussed the problem of principle and agent in firm governance and economic contracting. Thus, as made famous by the institutonalists Berle and Means (1932) and Galbraith (1966), there may occur a "separation of ownership and control” in the firm, causing managers to pursue other goals than profit maximization. 
Commons also amends the orthodox model of human rationality. Behavior and choice are rational, but only within bounds. Thus, Commons (IE, 874) advocates a model of what Herbert Simon (1982) later called "bounded rationality" on the grounds that rational choice is significantly constrained by "passion, stupidity, and ignorance.” [Simon (1982, p. 449) states that Commons was one of his sources for the bounded rationality concept.] Today these factors are called emotional affect, limited cognitive ability, and imperfect information. Commons gives great stress to the role of emotions in disrupting/distorting rational choice, particularly from feelings of fear, insecurity, and injustice. He says, for example, "Let anarchy surround him... and he reverts at once to animal fears that crowd out reason with its entire scheme of rights and duties... When his rational expectations are gone the savage in him takes possession” (LFC, p. 364). For similar reasons he states "of all human emotions... injustice is the most destructive" (p. 366). The implications are that rationality is to some degree a learned form of behavior, cannot always be exercised because of cognitive and information limitations, and can be seriously disrupted (and, paradoxically, sometimes improved) by strong emotional states (Kaufman, 1999b).

Another element of bounded rationality is imperfect information. Commons follows Knight (1921), Austrian economists, and post-Keynesian economists in this regard and stipulates that the decision maker faces an environment characterized by a significant amount of fundamental uncertainty. Thus, he (IE, p. 107) states that institutional economics "investigates how our own minds and the world around us actually behave in a society of human beings whose future is frankly recognized as unpredictable but which can be controlled somewhat by insight and collective action.” 
Fundamental uncertainty precludes, in turn, a closed system economic model and equilibrium solutions.

Commons also introduces qualifications into economists' treatment of selfinterest. First, while orthodox economics typically exalts the positive function played by self-interest via the invisible hand, Commons notes that in a world of imperfect information and property rights self-interest can easily turn into a destructive and antisocial force as people engage in cheating, lying, and misrepresentation. In the NIE Williamson (1985) models this dark side of self-interest as “opportunism.” The second qualification Commons introduces is to note that human beings also have other "self" motives and needs besides self-interest. An example stressed by Adam Smith is self-love, while others are self-esteem, self-actualization, self-efficacy, and self-worth. These other self motives in part shape the direction self-interest takes (e.g., self-love and self-esteem cause people to spend much effort and resources to maintain and advance their relative position in organizations and society), while in some cases these motives lead to behavior that are difficult to explain with orthodox theory. An example is internally motivated behavior (Kaufman, 1999a).

Internally (intrinsically) motivated behavior arises where people pursue a line of activity for its own sake or due to some internally generated drive, such as for selfrealization or the thrill of discovery/accomplishment. In neoclassical utility theory, behavior is extrinsically motivated because it arises from the pursuit of utility (satisfaction) residing in external objects and ceases once the optimal allocation or configuration is achieved. Such behavior, indeed, is essential to the entire notion of equilibrium, as is represented by the stable tangency position between a budget constraint 
and indifference curve. One reason institutional economists such as Commons find the equilibrium concept of limited applicability is precisely because people demonstrate considerable amounts of intrinsic motivation, causing them to pursue activities and goals with no equilibrium resting point or even direct relationship to externally specified benefits or costs.

As an example, Commons (IE, 874; Gonce, 1976) praised the entrepreneur as a key actor in economic growth, noting that these people are partly motivated by profit but also by an internal drive to accomplish and create in the face of a fundamentally uncertain future. Thus, while neoclassical theory emphasizes maximizing static efficiency through marginal decision rules and an optimal equilibrium allocation of resources, institutional (and Austrian) economics emphasizes the dynamic process of growth that comes from entrepreneurship and the development of new products, processes, and technologies - developments not well suited to marginal analysis nor best stimulated in many cases by an allocatively efficient perfectly competitive market. Also important to growth are the character of the people and the legal and institutional framework (Soto, 2000), while the amounts of labor and capital emphasized in neoclassical production function studies are of secondary importance.

Exchange, Coordination, and Production. This institutional model of the human agent is crucial for the logical development of the next theoretical component, the processes of coordination, exchange, and production. I start with exchange.

Because of division of labor and specialization, people become interdependent and must engage in exchange to acquire the necessities of life. A task for economic theory, therefore, is to model this process. The way orthodox economics does this is to 
model the exchange process as taking place through markets. Markets may take many forms, but the base-line or core version is a competitive market. The two sides of the market are represented by a demand curve and supply curve and these establish the equilibrium price and quantity. The quantity variable is usually specified as the amount of some good or service per time period; the price variable is market-determined and coordinates demand and supply.

Commons modifies this model in several important respects. To start, he notes that on deeper analysis it is not physical units of some good and service that are exchanged but the rights of ownership to these goods. Thus, he (ECA: 45, emphasis in original) observes "When the manufacturer sells his shoes, or the farmer sells his wheat, it becomes a 'commodity,' meaning anything that is bought and sold. But he does not sell the shoes, he alienates his ownership of the shoes, and he does not sell the wheat, he transfers its ownership....Prices are paid, nor for physical objects, but for the ownership of objects." Coase (1988a, p. 656) makes the same point when he says that what are traded on markets are not physical goods but rather "bundles of rights, rights to perform certain actions.”

When orthodox theory puts the Q (quantity) variable on the horizontal axis of the demand/supply diagram, it is implicitly assuming a condition of zero transaction cost and, hence, a regime of complete contracts, for only with complete contracts will the property rights traded in the market exactly match the goods and services (including money and other credit instruments) the buyer and seller deliver to each other. A contract is complete "when it is possible, at the moment of signing, to foresee all the circumstances that could arise while it is still in effect, and to set out verifiable clauses 
for each of them" (Cahuc and Zylberberg, 2004, p. 308, emphasis in original). Complete contracts and zero transaction cost (to be defined shortly) are crucial to the invisible hand conclusions of the neoclassical model because only then do market prices accurately reflect opportunity costs, all margins on exchangeable goods are priced, all gains from trade are realized, and conflict is obviated. Stated another way, complete contracts are what makes exchange frictionless and timeless and thus allows Walrasian theory to be institutionally empty and neutral. It is for this reason, as earlier noted, that a model of “imperfect man" is a prerequisite for a meaningful institutional economics.

In Commons' model, decision-makers have imperfect information and bounded rationality and confront an external environment with important elements of fundamental uncertainty. Hence, all contracts are necessarily incomplete and a potentially large gap opens between the property rights the buyer and seller agree to exchange and the quantities and values that are actually delivered. Incomplete contracts, in turn, permit a host of market failures and sources of inefficiency in exchange. With incomplete contracts and poorly specified and partitioned property rights, for example, some markets will be missing and others will set prices through small numbers administration and bargaining. Likewise, externalities will be rife and, indeed, arise in every exchange (Schmid, 1987). Numerous other contracting problems unknown to the Walrasian world of perfect competition also emerge, such as principal-agent problems, moral hazard, noncooperative bargaining, and hold-up effects. In labor markets, incomplete contracts and the human nature of labor also make supply and demand curves interdependent -- a change in the price of labor affects employee work effort and shifts the labor demand curve and with referent-dependent preferences the labor supply curve also shifts (Slichter, 
1931, p. 626) -- and render the former ill-defined (to be explained). Without a welldefined demand and supply curve, the core of the neoclassical model loses coherence.

Incomplete contracts also forge a link between the economics of Commons and Keynes at key points and help explain business cycles and non-market clearing outcomes (Atkinson and Oleson, 1998). The fundamental reason flexible wages cannot eliminate unemployment, argued Keynes (1936, p. 11), is because workers can only bargain about money wages in a capitalist labor market, but it is real wages that determine the demand for labor - implying unemployment may persist because of a missing institution, while he noted that in practice money wages are rigid downwards because of workers' concern for their relative wage position (p. 14) Also, with contractual incompleteness economic agents have a need for a human-made institution called "money" and it is the existence of money, along with the separation between real and nominal magnitudes that contract incompleteness allows, that causes business cycles (IE, p. 892). Contract incompleteness also means that expectations of the future (what Commons calls "futurity") are crucial since economic agents agree to exchange property rights today but in many cases only reap the benefits and bear the costs months and years in the future. Since people are emotional and boundedly rational beings, their expectations reflect "animal spirits” and collective moods of pessimism and optimism, making prices and expenditures both more volatile and non-correcting. These considerations, along with the general institutional proposition that the economy should be modeled as an unfolding process, means that economic theory should be constructed in real time - a proposition also fundamental to post-Keynesian economics (Davidson, 1994). 
Economic theory, of course, needs a way to conceptualize and model all of these "frictions." Toward this end, Commons invented the concept of a transaction. According to Commons, a transaction is the fundamental unit of measurement in institutional theory. He defines it as "a legal transfer of ownership” (IE, p. 55). He goes on to say (p. 58, emphasis in original), "Transactions, as thus defined, are not the 'exchange of commodities' in the physical sense of 'delivery,' they are the alienation and acquisition, between individuals, of the rights of future ownership of physical things, as determined by the working rules of society.”

Having defined the transaction as a transfer of legal ownership, Commons distinguishes three types of transactions: bargaining, rationing, and managerial. They are differentiated on the basis of the manner in which ownership rights are transferred.

The bargaining transaction is made by legal equals (if not economic equals) who exchange or trade property rights and ownership interests through voluntary agreement. Typically this occurs through markets and prices reflect the terms of trade. Bargaining transactions are the hallmark of a capitalistic market economy.

Rationing transactions (or "administrative transactions") are the product of command between a legal superior and legal inferior. A rationing transaction takes place when (ECA: 48), "either the quantity or the price, or both, are determined by some superior power." The superior power Commons had in mind is some unit of government, such as when a dictator issues a unilateral command, a legislature passes a law, or a court issues an edict that in some respect transfers property rights from one person or use to another. A centrally planned economy relies on rationing transactions to price and/or allocate resources, as do individual capitalist firms in making their internal resource 
allocations (suggesting firms can be viewed as a microeconomic version of central planning).

The managerial transaction takes place within firms and other institutions devoted to the creation of wealth. In broad form it is similar to a rationing transaction because it transfers ownership through command and vests a legally superior person with the ability to order a legally subordinate person to do the former's bidding (within limits). The managerial transaction occurs, for example, when the entrepreneur uses other people's purchased labor as a factor input in production. In this sense, it is coterminous with Williamson's (1985) concept of "hierarchy" (an organization with a "boss" and one or more subordinates). For purposes of production, an inanimate factor input can be directly utilized and the entrepreneur's property right in it gives him/her authority to extract as much "use value" from it as possible. When the firm purchases labor, however, in a world of incomplete contracts it gains a property right only to an ill-defined and highly variable amount of labor power embodied in a human being (an insight Commons got from Marx). Thus, when an employee is hired the transfer of ownership of labor power is still incomplete and one more transactional step is required before the firm gains the labor power it needs to commence production. This transfer of labor power from worker to firm is the "managerial transaction," and is accomplished by use of orders, rules and regulations, functional business specialists (e.g., human resource managers), supervisors, and various rewards and penalties.

Notice should be given to the fact that Commons has substantially broadened the orthodox theory of exchange. Exchange of property rights in neoclassical economics takes place through markets and is coordinated by price; in Commons' institutional 
economics exchange it takes place (principally) through two institutions - markets and hierarchial organizations, and is coordinated by two mechanisms - price and command. [Schmid (1987) notes that property rights can also be exchanged as a unilateral grant.] This conceptual dichotomy is clearly evident in Commons’ statement at the beginning of IE (p. 7), “All that Communism, Fascism, or Nazism needs to abolish historic capitalism is to abolish bargaining transactions and to substitute for them the managing and rationing of a planned economy.”

If there are alternative methods for exchanging property rights, the question immediately emerges: which mode is preferable, and under what conditions? In other words, the choice of market versus hierarchy becomes an endogenous variable, rather than an exogenous variable as in neoclassical economics. The key insight of Coase, and the central theoretical proposition of NIE, is that the choice of transactional mode turns on the relative cost of making the transactions; that is, on transaction cost. This insight, and its conceptualization, is the strategic part of institutional theory that Commons did not work out and is where the NIE makes a fundamental contribution. Paradoxically, however, although Commons never explicitly defined the concept of transaction cost, such a definition is implicit in his work and represents, I believe, an analytically superior version to that developed by Coase, Williamson and others in the NIE.

To get to Commons’ version of transaction cost requires one other distinction. He differentiates between proprietary (exchange) and production (engineering) sides of the economy (IE: 251-59). A transaction is a social "man-to-man" relation because property rights are socially created and transferred between people, while production is a physical "man-to-nature" relation because the services of physically-constituted factor 
inputs are transformed into outputs via a technologically determined production function. Thus, the acts of production and transaction are separable and orthogonal -- a transaction is by definition the process by which an entrepreneur trades or otherwise acquires ownership rights to factor services (and sells the ownership rights to the newly created goods and services); production is the process in which an entrepreneur transforms factor inputs already owned into new forms of material wealth (use values). In practice, the dividing line between the managerial transaction (the separation of labor power from the worker and transfer to the employer) and the use of this labor power in production is difficult to distinguish.

With this distinction in mind, Commons' theory directly leads to a definition of transaction cost. Since a "transaction" is a legal transfer of rights of ownership, "transaction cost" is the cost of the resources used up in effectuating this transfer of ownership rights. Transaction cost is thus intimately connected to the costs of contracting and, in particular, arise at each of three stages of the contracting process (ECA:53): the ex ante costs of negotiating the contract, the drawing-up and execution of the contract, and the ex post performance and enforcement ("administration") of the contract. Evidently, the only way for complete contracts is to have zero transaction cost, leading to the conclusion that a basic dividing line between Walrasian (orthodox) and non-Walrasian (heterodox) economics is the divide between zero and positive transaction cost for the former is an institutionally empty economy of self-regulating competitive markets and the latter is a mixed economy of imperfect markets and "non-markets" (firms, etc.) that is not self-regulating and thus requires managed coordination and control. 
This definition of transaction cost is broadly similar to that proffered by Coase and Williamson -- i.e., (paraphrased) ex ante and ex post costs of contracting (Coase, 1988b: 6; Williamson, 1985: 20). However, Commons’ schema maintains a clearer separation between production cost and transaction cost. Transaction cost is the value of the real resources used to effectuate a transfer of ownership rights, production cost is the value of the real resources used up in the production of a good or service once ownership rights to inputs have been obtained. Williamson, by way of contrast, defines transaction cost to also include intra-firm exchanges of goods and services (those already owned by the entrepreneur). From a legal perspective this confuses physical "delivery” with transfer of ownership, from an economic perspective it mixes production and transaction costs.

With this definition of transaction cost, we can now return to the choice of transactional mode. In the NIE this is frequently framed as the choice of "make versus buy." In neoclassical economics exchange is assumed to take place through markets and the endogenous variables are the equilibrium price/quantity. Institutional economics, however, recognizes that transactions may take place outside of markets. A classic illustration is when a firm decides to vertically integrate, thus taking a transaction out of the market and internalizing it within the firm (suggesting that the size and existence of markets is, in part, a choice variable of firms). Commons' model provides a microeconomic decision rule for determining the "make versus buy" vertical integration decision and, also, a macroeconomic explanation for when societies will choose a "make" economy of central planning versus a "buy" economy of market capitalism.

Regarding the vertical integration decision, Firm A can either make a good or service in-house or buy it from Firm B, whichever entails the least cost. The cost of the 
"make" option is per unit production cost (including a normal profit), $\mathrm{PC}_{\mathrm{A}}$, and managerial transaction cost, $\mathrm{MTC}_{\mathrm{A}}$. The cost of the "buy" option is the product price charged by Firm B, reflecting its production and managerial transaction cost and any above-normal profit margin, and also per unit bargaining transaction cost, $\mathrm{BTC}_{\mathrm{A}}$ from using the market. Thus, the "make" option is preferred if $\mathrm{PC}_{\mathrm{A}}+\mathrm{MTC}_{\mathrm{A}}<\mathrm{PC}_{\mathrm{B}}+\mathrm{MTC}_{\mathrm{B}}+$ $\mathrm{BTC}_{\mathrm{A}}$. (I assume competitive product markets, so Firm B earns only normal profit which is included in $\mathrm{PC}_{\mathrm{B}}$ ). If transaction cost is zero in both dimensions, the decision is "neoclassical" in that "make versus buy" turns solely on relative levels of production cost between the two firms. If both firms have identical production cost structures, Firm A will choose the "make option" as long as its managerial transaction cost (or, more simply, "management cost") is less than the sum of the market transaction cost and Firm B's management cost. Although not explicitly shown above, the "make" option of integration can also be motivated by the prospect of monopoly profit on the part of Firm A.

At a macroscopic level of comparative economic systems, Commons' theory also provides an explanatory framework for "make versus buy.” He distinguishes between an economy of "extreme individualism" and "extreme collectivism." In an earlier article (Kaufman, 2003), I have suggested these terms can be thought of as two endpoints in economic organization. Extreme individualism, or "perfect decentralization," is an economy organized at the lowest possible level of disaggregation - that is, a "buy" economy composed solely of one person production units, such as an economy of family farms or one-person firms, where the division of labor is entirely coordinated by price and intermediate goods and factor inputs are acquired through bargaining transactions. The polar opposite is "perfect centralization" where the economy 
is organized as one giant "firm” (a "make” economy) and the division of labor is entirely coordinated by command and all intermediate goods and factor inputs are produced (or reside) within the organization and are acquired through rationing and managerial transactions.

The model of perfect decentralization corresponds to a Walrasian competitive general equilibrium economy; the model of perfect centralization corresponds to a socialist centrally planned economy. Based on Commons' ideas, I have developed a "periodic table" that identifies the five fundamental variables (decision-making, utility functions, production functions, property rights, and sovereignty, along with the degree of complementarity and non-separability within and among them) that determine all forms of economic organization.

For example, where decision-making is perfect (perfect human rationality and information) and property rights are perfectly divisible, tradable, and enforced, the economy is one of perfect decentralization; where decision-making is perfect but property rights are completely indivisible and non-tradable the economy is one of perfect centralization. The former is characterized by zero bargaining transaction costs and is coordinated by an omniscient auctioneer, the latter is characterized by zero rationing and managerial transaction cost and is coordinated by an omniscient central planner (or nation-state “CEO”). Ultimately, the key decision variable in determining the form of economic organization is whether private property rights exists and can be traded, thus supporting Commons' contention that government (or "sovereignty") and the rules issued by the institution of government concerning property rights are the most fundamental determinant of economic activity. Seen in this light, economics spans both market and 
non-market forms of economic organization, includes both the subjects of markets and management and the theories of price and administrative coordination, rests fundamentally on rules about ownership, and is always and everywhere "political economy" and "institutional economy.” Likewise, in real world economies that have both positive bargaining and rationing transaction cost, the economy is neither all price coordinated nor all command coordinated but some combination of the two, yielding different forms of a mixed economy. Concrete examples of this type of institutional theory in operation are the literatures on “employment systems” (e.g., Marsden, 1999) and "varieties of capitalism” (e.g., Hall and Soskice, 2001), and the role that "institutional complementarities” play in giving rise to a small number of discrete institutional forms (Aoki, 2001; Höpner, 2005). Similarly, positive transaction cost and asset specificity (a technological form of complementarity) explain the formation and structure of internal labor markets (Doeringer and Piore, 1971; Williamson, Wachter and Harris, 1975). Descending to a lower level of analysis, Commons' theory of institutional economics also provides new ways of conceptualizing and understanding markets and firms.

It is a fair statement that neoclassical economists simply assume markets and firms exist and spend little time inquiring into the institutional infrastructure of these entities (Streeck, 2005). Abolafia (2005, p. ix) notes, for example, that the most important reference work in economics, The New Palgrave Dictionary of Economics (Eatwell, Milgate, and Newman,1987), quite astoundingly has no entry on "markets.” This type of a priori treatment of fundamental constructs led Coase $(1988$, p. 3$)$ to lament that what 
we have in economic theory is "consumers without humanity, firms without organization, and even exchange without markets.”

First consider in more detail markets. Markets do not exist in nature but are human-made institutions that require real resources to create and operate. Furthermore, markets operate only in the context of a body of working rules that determine the nature of the good or service being exchanged, the pool of potential traders and conditions of entry and exit, the procedures governing interaction between buyers and sellers and what methods and practices can and cannot be used, and the sanctions used to enforce obedience to the rules. In this spirit, Coase (1992, p. 718) declares in his Nobel address, "It makes little sense for economists to discuss the process of exchange without specifying the institutional setting within which trading takes place, since this affects the incentives to produce and the costs of transacting.”

The importance of this perspective can be appreciated by considering the neoclassical theory of price determination. As noted earlier (the quote of Kniesner and Goldsmith), the theoretical heart of neoclassical economics is the model of auction-type competitive markets. An auction market, however, does not emerge out of thin air; rather, it is an example of what Alfred Marshall (1920, p. 326) called a "highly organized market,” such as the New York Stock Exchange or Chicago Board of Trade, and functions only because of specially-created rules and institutional infrastructure . For example, rules establish the precise characteristics of the products traded (e.g., No. 2 winter wheat); a central exchange is created that coordinates buying and selling and announces prices akin to Walras' auctioneer; the central exchange separates buyers and sellers so they are anonymous and make offers and bids based solely on price; and 
institutions are created that quickly disperse information to buyers and sellers and minimize the costs of transacting. The result is real world markets that closely approximate the textbook model of pure competition, which is to say a situation where prices clear the market and quickly rise and fall in reaction to changes in demand and supply. Indeed, price volatility in highly competitive markets is so pervasive that additional institutions called "futures markets" are typically created in order to keep speculation from becoming destabilizing.

The question, of course, is whether many or most real world markets resemble auction markets in structure and performance - not necessarily in terms of every descriptive detail but as a reasonable first approximation. Empirical evidence suggests the answer is no with regard to structure, and that this makes a large difference in terms of performance (Abolfafia, 2005). The reason is because most markets lack the central institution crucial to an auction market - an intermediary organization between buyers and sellers that collects the bids and offers and sets the parametric market-clearing price. If no such exchange exists, then some other institution, set of rules, and process has to set the price (or wage). In most markets, this function is performed by business firms, although often supplemented and in some cases supplanted by bargaining and negotiation (Robinson, 1978). In the markets for cars, restaurant meals, and movies, for example, firms choose the price and present it to buyers on a "take it or leave it" basis, as they do with wages in labor markets. This fact suggests that these firms face downward sloping demand curves in product markets and upward sloping supply curves in labor markets, implying prices and wages are not parametric but subject to choice. A variety of market 
imperfections, however, create room for higgling and thus the posted price (or wage) may be closed through an implicit or explicit form of bargaining (as in many auto sales).

Several implications flow from these observations. First, most prices (including wages) are administered prices and are thus set to maximize the interests of the institution that sets them (firms). These prices sometimes allow room for negotiation, however, and the final price in these cases is also a bargained price. Thus, one may assert that the core of neoclassical microeconomics is the theory of market-determined prices, while the core of institutional economics is the theory of administered/bargained prices. Second, while administered/bargained prices are undoubtedly constrained (perhaps greatly) by market forces, the fact they are set by firms or through bilateral bargaining means as a general premise that they are neither market-clearing nor very flexible (witnessed by the absence of futures markets for labor and most goods). Third, prices can only be completely market determined if there are zero transaction costs, while they take on some element of an administered/bargained price whenever transaction cost is positive. Fourth, the model of a perfectly competitive labor market is logically contradictory since it presumes zero transaction cost but in this situation a labor market will not exist since firms hire all labor services from independent contractors in product markets (Coase, 1937). Fifth, this dividing line between zero and positive transaction cost also determines when the familiar diagram of price determination by supply and demand can exist as a meaningful (well-defined) theoretical construct. The reason is that a welldefined market supply curve only exists in a perfectly competitive market (derived as the sum of the marginal cost curves of the individual firms), while in an imperfectly competitive market individual firms have no well-defined supply curve, as demonstrated 
in most elementary economics textbooks for the case of monopoly. By similar reasoning, a well-defined labor demand curve and market-determined wage cannot be derived for an imperfectly competitive labor market (Fleischer and Kniesner, 1980, p. 198). Given the ubiquity of transaction costs, institutionalists (e.g., Tool, 1991, p. 21) would agree with the contention of Joan Robinson (1933) that the neoclassical penchant to treat perfect competition as the general case and monopoly as the special case should be reversed (where monopoly is broadly defined).

These implications about price theory are not stated per se in any of Commons' theoretical works. It is evident, however, in his discussion of bargaining transactions that he assumes the general case is one of imperfect competition, partly because he assumes markets are characterized by a range of indeterminateness in offers and bids (e.g., IE, 59) and partly because he lays great stress on the role of strategic interaction in price setting (called “negotiational psychology”, IE, p. 90; Biddle, 1990). What is more important, however, is the general observation that the power of a theory is to generate cause-effect statements and empirical hypotheses and, given the implications noted above, by this standard Commons has indeed presented us with a theory of generality and substance.

Commons' institutional perspective also yields interesting and often nonneoclassical insights and predictions about the theory of the firm and theory of production.

As a generalization, neoclassical theory treats the firm as a production function, assumes the goal of the firm is maximum profit, assumes deterministic and downward sloping marginal revenue product (factor demand) schedules, postulates that firms operate at (or gravitate toward) an equilibrium output level where marginal revenue 
equals marginal cost (MR=MC), that market forces pressure firms to operate on their efficiency frontiers, and firms have no power over employees. None of these propositions, however, are acceptable or likely to be valid as a general case from an institutional perspective.

The firm, from Commons’ perspective, is an institution or governance structure. The operation and performance of firms, like markets, thus has to be understood in terms of the rules that structure them and the goals of the people who develop and enforce the rules. The first casualty of this observation is the neoclasscial a priori and universalistic profit maximization assumption. Viewed as a governance structure, the objective function of every organization, be it a firm or a labor union, is determined through a political process in which the governance rules and distribution of property rights (e.g., endowments and power) determines whose interests count. When the firm is owned and managed by one person and operates in a largely competitive environment, it is reasonable to assert that the goal of the firm is maximum profit. But, when owners (e.g., shareholders) are highly dispersed, the firm is effectively run by the salaried managers, and particularly in cases where markets have significant imperfections, the governance structure is such that the managers have some discretion to pursue their self-interested goals - goals which may include maximizing growth or size, maximizing executive compensation, or enjoying the "quiet life.” Today this idea has moved into mainstream economics under the aegis of principle-agent theory but whether it is internally consistent with the core of neoclassical economics is less clear (to be discussed later).

Other core parts of the neoclassical theory of the firm are equally compromised when put under the lens of institutional economic theory. For example, the theory of the 
firm postulates a well-defined and downward sloping short-run marginal product schedule for labor, deduced as a solely technological phenomenon attainable from adding more units of labor to the production function. Institutionalists (e.g., Lester, 1964; Dow, 1997) object to this on two grounds: first, it treats labor as similar to capital, land, and other inert commodities when labor is actually embodied in living human beings and, second, it again assumes zero transaction cost and complete contracts when such do not exist in the real world. The result is the managerial transaction has a significant element of indeterminacy that has to be closed through bargaining, human resource management practices, punitive measures (e.g., threat of termination), and other devices. The reasons are, first, that - as Marx first emphasized -- labor power is volitionally supplied by workers, depending on their morale, feelings toward the employer, interest in the job, etc., unlike the determinate amount of BTUs or RAM that goes into the production function from every unity of homogenous coal or computers. Thus, in the usual diagram the marginal product of coal or computers is determinate and can be drawn as a welldefined downward-sloping schedule, but the marginal product of labor is highly variable and can only be assumed to yield a determinate schedule if the volitional capacity of labor is omitted or, alternatively, the employer and employee are assumed to negotiate a complete and fully enforced labor contract ex ante to production (so that that workers supply the agreed-upon amount of labor power contracted for in the wage bargain). As nearly all neoclassical economists (e.g., Stigler, 1952, p. 200) admit, however, human work effort is highly variable and employment contracts are notoriously incomplete. In addition to these lacunas, the standard theory of the competitive firm is able to generate an equilibrium short-run output level by assuming production is subject to the 
law of diminishing returns so that at some point there is a $\mathrm{MR}=\mathrm{MC}$ equilibrium. The problem, from an institutional perspective, is that the law of diminishing returns is (again) postulated as an a priori assumption and is almost never subjected to empirical verification. From an institutional perspective, the law of diminishing returns is not a universal phenomenon, at least over a large part of the relevant range of production, but rather applies as a useful first approximation to only a subset of production situations (e.g., farming). Thus, institutionalists insist on empirically informed priors and when they examine the empirical evidence on the behavior of production cost they find that in many lines of production marginal and average variable cost curves are horizontal or declining until close to the technical full capacity level of production (Lee, 1998). A principal reason, in turn, is that the marginal analysis underlying neoclassical economics has validity only as long as economic relations are divisible, while significant aspects of cost are indivisible (e.g., joint costs, team forms of production, fixed costs, all of which can lead to some version of increasing returns) and thus have the "collective" aspect (as opposed to "individualistic" or divisible aspect) emphasized in institutional economics. The implication is that setting MR=MC may not be an operationally viable decision rule for a firm and, hence, they determine short-run output (and employment) using an alternative procedure (Lester, 1946). One test of these alternative theories is to ask: would most real world firms be willing to produce more output if they could sell it at the going price? The neoclassical theory of the firm answers "no" (since doing so would by logical implication reduce profit) while institutional theory answers "most likely yes." Similarly, the fact that most workers are not indifferent to being laid-off or fired (as they 
would be with a horizontal labor supply curve to the firm) also suggests that labor markets do not operate at a competitive market-clearing position.

Another distinguishing difference between neoclassical and institutional economics concerns the linkage between efficiency and equity. As Stiglitz (2000) notes, the central tenet of the Fundamental Welfare Theorems of neoclassical economics is that issues of distribution (equity) can be separated from issues of efficiency. Thus, Walrasian theory asserts that the inequality of initial endowments, or distribution of market rewards, does not affect the ability of a perfectly competitive economy to generate the Pareto optimal level of output. The reason is that economic agents are modeled as self-interested individualists (utility functions are independent) and, thus, issues of fairness and distribution do not affect individual behavior (per the observation of Rees, 1993, p. 243, that "the neoclassical theory of wage determination.... has nothing to say about fairness"). It is a central tenet of institutional economics, however, that economic agents are social beings and that considerations of fairness and equity are ever-present. If this is the case, the effort provided by workers in production is a positive function of perceived equity (e.g., procedural and distributive justice), creating a link between efficiency and fairness. Further, Commons contends that if market rewards are viewed as unjust then the economic players at some point refuse to honor the rules or even play the "game," creating not only inefficiency but also the possibility of sabotage and rebellion. Thus, he asserts that prices cannot be at a long-run equilibrium unless they also pass the test of reasonable value. That is, market endowments, processes, and outcomes must be widely perceived as falling within the limits of fairness or otherwise they will be changed through collective action, leading to further changes in prices. For this reason institutional 
economists contend that considerations of fairness and social justice must be introduced into economics on purely positive (theoretical) grounds since economic behavior is strongly influenced by both.

Finally, an implication of neoclassical theory is that employers have no net power advantage over individual employees since, in a competitive labor market, they can easily quit and seek work elsewhere. Alchian and Demsetz (1972, p. 777) claim, for example, that the firm "has no power of fiat, no authority ....Telling an employee to type this letter rather than file that document is like telling a grocer to sell me this brand of tuna rather than that brand of bread.” But, from Commons’ perspective, this characterization is highly inaccurate. Many workers face substantial constraints on mobility because external labor markets are imperfect, separation from internal labor markets entails significant costs, and the law explicitly gives the employer authority to tell the worker what to do (within limits) and the right to terminate the worker "at will" for non-compliance.

Social Welfare Objectives. I wish to end the overview of Commons' institutional economics with a very brief discussion of social welfare objectives.

Commons was not a classical liberal nor a European-style social democrat but a “social liberal.” He sought maximum liberty for individuals, but this liberty had to be a "positive liberty" where people had not only minimalist constraint on satisfying their preferences ("the "negative liberty" of classical liberalism) but also a reasonable degree of power (i.e., resources, as made available by rights) to actually attain them (Fried, 1998). It was for this reason that he advocated unemployment insurance and, more radically, a right to some form of gainfully-earned income, on the grounds that "Free will 
is illusory if it does not end in free action, and free action is impossible where society has not yet overcome the hard physical facts of necessity” (Commons, 1899, p. 135). Similarly, he favored voluntary employer initiatives and market solutions to social problems (IE, p. 875), but employers and markets had to induce action by “persuasion” (a choice based on attractive alternatives, such as good wages and hours) rather than “coercion” (a choice compelled by lack of good alternatives, such as induced by hunger and fear of joblessness).

The existence of (unreasonable) coercion in economic exchange, in turn, provided the institutionalists with an intellectual rationale for rules that abridge freedom of contract, such as a minimum wage law and union contract, for the courts had long held that coerced contracts are null and void. In this spirit Commons and Andrews declare (1936, p. 372), "the inequality in withholding power between employer and employee is so great [due to unequal property rights, market imperfections and substantial unemployment] that the term bargaining is a misnomer," and then continue (p. 373) “The need for collective bargaining arises from the serious discrepancy in 'withholding power' between the individual employer and the individual wage earner, a discrepancy which tends to result in terms of employment highly oppressive to the worker and injurious to society as a whole.... It is a case of the necessities of the laborer pitted against the resources of the employer.” While from a neoclassical perspective collective bargaining in a competitive labor market results in "monopoly wages" and resource misallocation, from an institutional perspective the tilted legal rules of the game (e.g., laws permitting unrestricted immigration but high tariffs on imported goods) may so favor the interests of capital that labor as a class nonetheless suffers from a form of "institutional exploitation" 
(Taylor, 1977). So viewed, collective bargaining increases the wage closer to what would prevail with more balanced (“competitive”) rules and rights (Kaufman, 2004d).

Starting from this ethical position, Commons became a labor economist early in his career because he saw that labor markets were the site of the worst coercion in capitalism; in the 1920s he became one of the nation's leading monetary economists because he saw that demand-deficient unemployment was the worst cause of economic coercion and monetary stabilization was the best solution; and throughout his career he advocated expanded collective bargaining, protective labor legislation and social insurance programs as a way to balance bargaining power, provide economic security (regarded as people's greatest economic desire) and give workers voice in the operation of industry (Gonce, 1976; Whalen, 1993, Kaufman, 1997). Stated another way, Commons believed in capitalism and free markets but both have to be fair, balanced, democratic and humane to attain and keep ethical legitimacy (Budd, 2004). To achieve these conditions, in turn, required that he set aside neoclassical economics, given its laissez-faire orientation and defense of existing economic outcomes (which serve the self-interest of the rich and powerful who have preponderant influence in setting the rules of the game) and become an institutional economist who actively seeks to change the rules of the game to achieve the aforementioned goals.

Given this ethical orientation, the next step is derivation of a more formal social welfare function with which to evaluate alternative economic outcomes. Neoclassical theory uses the criterion of efficiency or Pareto optimality. An outcome is efficient when resources have been allocated such that it is impossible to make one person better off 
without harming another person. Personal benefit and harm are measured in terms of individual preference relations, usually defined over alternative consumption goods.

Commons and fellow institutionalists advocate an expanded social welfare function. Dispute exists about the precise nature of the institutional social welfare function (see Samuels, 1997), but I outline what I interpret Commons’ position to be (Kaufman, 2005).

Efficiency is a crucial objective since the maintenance and advancement of the human condition is clearly promoted from attaining as much output as is possible from society's limited resources. Thus, Commons states (IE, p. 6) "It is for this reason of scarcity that I make efficiency a universal principle.”

But Commons goes on to expand the objectives of economic policy to include two other normative goals: equity (social justice) and human self-development and selfrealization. As noted above, Commons believed a reasonable level of equity promotes efficiency and thus the two are in substantial part complements. But quite apart from any efficiency consideration, Commons argued that reasonable fairness/social justice should also be pursued as an explicit welfare goal on account of its intrinsic ethical value. He notes in $I E$ (p. 706), for example, that equality is one of the "fundamental wishes of all mankind," while elsewhere Commons observes that the public accepts free trade only as long as it is also fair trade (IE, p. 63)

The highest-order welfare goal in Commons' social welfare function is that the economy be structured and operated so as to promote maximum opportunities for personal growth and development. His teacher and mentor Richard Ely (1938, p. 66) stated this idea with the dictum that the end goal of economic activity is "the true growth 
of all mankind; namely, the full and harmonious development in each individual of all human faculties," a theme Commons echoes with the statement that the end goal is "[to] gradually develop all that is highest in every son of man” (quoted in Gonce, 1996).

In effect, Commons subscribes to the Biblical instruction that "man does not live by bread alone" and an economy should thus be judged in terms of a broader array of criteria than just efficiency. In modern terms, the social welfare function of institutional economics can be thought of as a quasi-lexicographic version of Maslow's hierarchy of needs - that is, the neoclassical objective of maximum efficiency is the first order (or bottom level) need that is given first priority but then arrayed in an ascending quasilexicographic ordering are other higher level objectives, such as equity and selfrealization (Lutz and Lux, 1988; Kaufman, 1990).

\section{Conclusion}

A common perception is that institutional economics lacks theory and therefore only one kind of economics exists - neoclassical economics. The purpose of this paper has been to demonstrate that both conclusions need substantial revision. Drawing on the work of John R. Commons, I endeavor to delineate the core theoretical and methodological principles of institutional economics - or at least his version and as I interpret and synthesize it, and illustrate the connections between institutional economics and other fields such as economic sociology. My claim is that Commons' writings, along with contributions from other institutional and heterodox economists - including a number of recent Nobel Prize winners (Schmid, 2001), not only yield theory and testable hypotheses but also provide the basis for an alternative heterodox paradigm in economics 
with a distinctive body of microeconomic and macroeconomic theory. I make no claim to have fully developed this paradigm or body of theory, but I do believe this paper has usefully outlined and described its essential premises and principles. On one hand, not everyone will agree with these distinctions and boundary lines; on the other, they are put forward with credible logic and supporting evidence.

The true test of a theory is that it yields interesting, useful, and empirically falsifiable predictions. The key concepts of institutional economics are bounded rationality, property rights, working rules, institutions, and the transaction and its most important working principles are positive transaction cost and incomplete contracts. With these, numerous implications and predictions concerning labor markets, labor outcomes and the employment relationship can be generated. Institutional economics, for example, provides a theoretical explanation for the existence of an employment relationship and endogenizes the boundary between firms and labor markets, thus providing a theoretical base for industrial relations (i.e., the study of the employment relationship) as a separate field in the social sciences (Kaufman, 2004c). Likewise, institutional economics suggests that rules and institutions structure external and internal labor markets and employment outcomes, thus making industrial relations an integral part of the study of labor economics as long maintained by earlier institutional and neo-institutional labor economists (Reynolds, 1950; Kerr, 1954; Dunlop, 1958). Regarding neoclassical labor economics, institutional theory demonstrates that the perfectly competitive labor market model is theoretically contradictory; explains the origin and consequences of principalagent, moral hazard, adverse selection and numerous other contracting problems in employment; predicts that labor markets are not self-correcting, wage rates are neither 
flexible nor fully compensating, firms' labor demand may not decline with a rise in wage rates, efficiency is related to fairness, firms in many cases have a power advantage over individual workers, and unions and government labor laws may increase (as well as decrease) economic efficiency. These insights give further credence to the observation of Streeck (2005, p. 255) that "free labor markets are impossible, and unregulated labor markets are neither free nor fair.”

Of course, some (perhaps many) mainstream economists will argue that all of these predictions can also be explained with some generalized version of neoclassical economic theory (Becker, 1976; Boyer and Smith, 2001). The challenge faced with this argument, however, is to demonstrate how this expanded/amended theory escapes the twin charges that it is fundamentally ad hoc relative to the Walrasian competitive core of the paradigm and in contradiction of the paradigm's most celebrated theoretical insight the Invisible Hand Theorem (Amable, Boyer, and Lordon, 1997). Neoclassical theory cannot explain everything and avoid tautology or ex post rationalization, hence opening up intellectual space and scientific need for an alternative heterodox paradigm. What I hope to have demonstrated is that the theoretical writings of John R. Commons provide many of the core ideas and concepts for such an alternative paradigm, and the basis for a stronger integration of the economic and social dimensions of human behavior.

\section{REFERENCES}


Abolafia, Mitchel. 2005. Markets. Northampton: Edward Elgar.

Amable, Bruno, Boyer, Robert, and Frederic Lordon. 1997. “The Ad Hoc in Economics: The Pot Calling the Kettle Black.” In A.. d'Autumne and J. Cartelier, eds., Is Economics Becoming a Hard Science?, pp. 252-75. Brookfield: Edward Elgar.

Aoki, Masahiko. 2001. Toward a Comparative Institutional Analysis. Cambridge: MIT Press.

Arrow, Kenneth, and Gerard Debreu. 1954. "Existence of an Equilibrium for a Competitive Economy.” Econometrica, Vol. 22, pp. 265-90.

Atkinson, Glen, and Theodore Oleson Jr. 1998. “Commons and Keynes: Their Assault on Laissez-Faire.” Journal of Economic Issues, Vol. 32 (December), pp. 1019-30. Barbash, Jack. 1976. “The Legal Foundations of Capitalism and the Labor Problem.” Journal of Economic Issues, Vol. 10 (December), pp. 796-810.

Becker, Gary. 1976. The Economic Approach to Human Behavior. Chicago: University of Chicago Press.

Berle, Adolf, and Gardiner Means. 1932. The Modern Corporation and Private Property. New York: Macmillan.

Biddle, Jeff. 1990. “The Role of Negotiational Psychology in J.R. Commons’ Proposed Reconstruction of Political Economy.” Review of Political Economy, Vol, 2 (1), pp. 1-25.

. 1991. “The Instrumental Presentism of John R. Commons.” In J. Brown and D. van Keuren, eds., The Estate of Social Knowledge. Baltimore: Johns Hopkins Press, pp. 84-105. 
. 1997. “Purpose and Evolution in Commons’s Institutionalism.” In G. Hodgson, ed., The Foundations of Evolutionary Economics: 1890-1973, Vol. 2 Northampton: Edward Elgar.

Blaug, Mark. 1997. Economic Theory in Retrospect, $5^{\text {th }}$ ed. Cambridge: Cambridge University Press.

Boulding, Kenneth. 1957. “A New Look at Institutionalism.” American Economic Review, Vol. 47 May), pp. 1-12.

Boyer, George, and Robert Smith. 2001. "The Development of the Neoclassical Tradition in Labor Economics.” Industrial and Labor Relations Review, Vol. 54 (January), pp. 199-203.

Boyer, Robert, and Yves Saillard. 2002. Régulation Theory. New York: Routledge. Budd, John. 2004. Employment with a Human Face: Balancing Efficiency, Equity, and Voice. Ithaca: Cornell University Press.

Cahuc, Pierre, and André Zylberberg. 2004. Labor Economics. Cambridge: MIT Press. Chamberlain, Neil. 1963. “The Institutional Economics of John R. Commons.” In Institutional Economics: Veblen, Commons, and Mitchell Reconsidered. Berkeley: University of California Press.

Champlin, Dell, and Janet Knoedler. 2004. The Institutionalist Tradition in Labor Economics. Armonk: M.E. Sharpe.

Cheung, Steven. 1988. “The Transaction Costs Paradigm.” Economic Inquiry, Vol. 36 (October), pp. 514-21.

Coase, Ronald. 1937. “The Nature of the Firm.” Economica, Vol. 4 (November), pp. 386 $-405$. 
. "The New Institutional Economics.” Journal of Institutional and Theoretical

Economics, Vol. 140 (March), pp. 229-31.

. 1988. “Blackmail.” Virginia Law Review, Vol. 74, pp. 655-76.

. The Firm, the Market, and the Law. Chicago: University of Chicago Press.

. 1992. "The Institutional Structure of Production.” American Economic Review,

Vol. 82 (June), pp. 713-19.

. 1994. Essays on Economics and Economists. Chicago: University of Chicago

Press.

Commons, John. 1893. The Distribution of Wealth. New York: Augustus M. Kelly (1963 reprint).

. 1899. “The Right to Work.” The Arena, Vol. 21 (February), pp. 131-42.

. 1919. Industrial Goodwill. New York: McGraw-Hill.

. 1924. Legal Foundations of Capitalism. New York: Macmillan.

. 1925. Reasonable Value. Unpublished manuscript. Madison: State Historical

Society of Wisconsin.

. 1934a. Institutional Economics: Its Place in Political Economy. New York:

Macmillan.

. 1934b. Myself. Madison: University of Wisconsin Press.

. 1934c. "Impromptu Address, Chicago Meetings of American Economic

Association on New Deal and Teaching Economics.” Unpublished paper,

Microfilm Reel 21, John R. Commons papers. Madison: State Historical Society of Wisconsin.

1950. Economics of Collective Action. Madison: University of Wisconsin Press. 
and John Andrews. 1936. Principles of Labor Legislation, $4^{\text {th }}$ ed. New York:

Harper \& Row.

Davidson, Paul. 1994. Post-Keynesian Macroeconomic Theory. Brookfield: Edward Elgar.

Dobbin, Frank. 2005. “Comparative and Historical Approaches to Economic Sociology.” In N. Smelser and R. Swedberg, eds., The Handbook of Economic Sociology, $2^{\text {nd }}$ ed., pp. 26-48. New York: Russell Sage.

Doeringer, Peter, and Michael Piore. 1971. Internal Labor Markets and Manpower Analysis. Lexington: Lexington Books.

Dow, Gregory. 1997. “The New Institutional Economics and Employment Regulation.”

In B. Kaufman, ed., Government Regulation of the Employment Relationship.

Madison: Industrial Relations Research Association, pp. 47-74.

Dunlop, John. 1958. Industrial Relations Systems. New York: Holt.

Eatwell, John, Milgate, Murray, and Peter Newman. 1987. The New Palgrave Dictionary of Economics. London: Macmillan.

Ely, Richard. 1938. Ground Under Our Feet: An Autobiography. New York: Macmillan. Fleischer, Belton, and Thomas Kniesner. 1980. Labor Economics: Theory, Evidence, and Policy, $2^{\text {nd }}$ ed. Englewood Cliffs: Prentice-Hall.

Frank, Robert. 1985. Choosing the Right Pond: Human Behavior and the Quest for Status. New York: Oxford University Press.

Fried, Barbara. 1998. The Progressive Assault on Laissez Faire: Robert Hale and the First Law and Economics Movement. Cambridge, MA: Harvard University Press. 
Furubotn, Erik. 1997. “The Old and New Institutionalism in Economics.” In P.

Kowslowski, ed., Methodology of the Social Sciences, Ethics, and Economics in the Newer Historical School. Berlin: Springer, pp. 429-63.

and Rudolph Richter. 1997. Institutions and Economic Theory. Ann Arbor:

University of Michigan Press.

Galbraith, John. 1966. The New Industrial State. Boston: Houghton-Mifflin.

Gigerenzer, Gerd, and Reinhard Selten. 2001. "Rethinking Rationality.” In G. Gigerenzer and R. Selten, eds., Bounded Rationality: The Adaptive Toolbox, pp. 1-12. Cambridge: MIT Press.

Gonce, Richard. 1966. The Development of John R. Commons' System of Thought. Ph.D. dissertation. Madison: University of Wisconsin. . 1976. “The New Property Rights Approach and Commons’ Legal Foundations of Capitalism.” Journal of Economic Issues, Vol. 10 (December) pp. 765-97. . 1996. “The Social Gospel, Ely, and Commons’ Initial State of Thought,” Journal of Economic Issues, Vol. 30, no. 3, pp. 641-65.

Granovetter, Mark. 1991. “The Social Construction of Economic Institutions.” In A. Etzioni and P. Lawrence, eds., Socio-Economics: Toward a New Synthesis, pp. 75-84. Armonk: M.E. Sharpe.

Grossekettler, H. 1989. “On Designing an Economic Order: The Contribution of the Freiburg School.” In D. Walker, ed., Perspectives on the History of Economic Thought, Volume II: Twentieth Century Economic Thought. Northampton: Edward Elgar, pp. 38-84. 
Hall, Peter, and David Soskice. 2001. Varieties of Capitalism: The Institutional Foundations of Comparative Advantage. Oxford: Oxford University Press.

Hicks, John. 1939. Value and Capital: An Inquiry into Some Fundamental Principles of Economic Theory. Oxford: Clarendon Press.

Hodgson, Geoffrey. 1999. Evolution and Institutions: On Evolutionary Economics and the Evolution of Economics. Northampton: Edward Elgar. . 2003. "John R. Commons and the Foundations of Institutional Economics," Journal of Economic Issues, Vol. 37 (September), pp. 547-76.

Höpner, Martin. 2005. “What Connects Industrial Relations and Corporate Governance? Explaining Institutional Complementarity.” Socio-Economic Review Vol. 3 (May), pp. 331-58.

Jacoby, Sanford. 1990. “The New Institutionalism: What Can It Learn from the Old?” Industrial Relations, Vol. 29 (Spring), pp. 316-40.

Kahneman, Daniel, Wakker, Peter, and Rakesh Sarin. 1997. "Back to Bentham? Explorations of Experienced Utility.” Quarterly Journal of Economics, Vol. 112 (May), pp. 375-405.

Kaufman, Bruce. 1997. "Labor Markets and Employment Regulation: The View of the 'Old Institutionalists’.” In B. Kaufman, ed., Government Regulation of the Employment Relationship. Madison: Industrial Relations Research Association, pp. 11-55. . 1999a. "Emotional Arousal as a Source of Bounded Rationality.” Journal of Economic Behavior and Organization, Vol. 38 (February), pp. 135-44. . 1999a. "Expanding the Behavioral Foundations of Labor Economics." Industrial and Labor Relations Review, Vol. 52 (April), pp. 361-92. 
. 1999b. "Emotional Arousal as a Source of Bounded Rationality.” Journal of

Economic Behavior and Organization, Vol. 38 (February), pp. 135-44.

. 2004a. The Global Evolution of Industrial Relations: Events, Ideas, and the

IIRA. Geneva: International Labor Organization.

. 2004b. “The Institutional and Neoclassical Schools in Labor Economics.” In D.

Champlin and J. Knoedler, eds., The Institutionalist Tradition in Labor

Economics. Armonk: M.E. Sharpe, pp. 13-38.

. 2004c. "Employment Relations and the Employment Relations System: A Guide

to Theorizing." In B. Kaufman, ed., Theoretical Perspectives on Work and the

Employment Relationship. Champaign: Industrial Relations Research

Association, pp. 41-76.

. 2004d. "Historical Insights: The Early Institutionalists on Trade Unionism and

Labor Policy.” Journal of Labor Research, Vol. 26 (Winter), pp. 1-32.

. 2005. “The Social Welfare Objectives and Ethical Principles of Industrial

Relations.” In J. Budd and J. Scoville, eds., The Ethics of Human Resources and

Industrial Relations, pp. 23-59.

Kerr, Clark. 1954. “The Balkanization of Labor Markets.” In E. Wight Bakke, ed., Labor

Mobility and Economic Opportunity. New York: Wiley, pp. 92-110.

Keynes, John. 1936. The General Theory of Employment, Interest and Money. New

York: Harcourt-Brace.

Knight, Frank. 1921. Risk, Uncertainty and Profit. New York: Harper \& Row. 
Kniesner, Thomas, and Arthur Goldsmith. 1987. “A Survey of Alternative Models of Aggregate U.S. Labor Market.” Journal of Economic Literature, Vol. 25 (September), pp. 1241-80.

Knight, Frank. 1935. “Book Review: Institutional Economics.” Columbia Law Review, Vol. 35, pp. 803-05.

Lazear, Edward. 2000. “Economic Imperialism.” Quarterly Journal of Economics, Vol. 115 (February), pp. 99-145.

Lee, Frederic. 1998. Post-Keynesian Price Theory. Cambridge: Cambridge University Press.

Lester, Richard. 1946. "Shortcomings of Marginal Analysis for Wage/Employment Problems.” American Economic Review, Vol. 36 (March), pp. 63-82. 1964. The Economics of Labor, $2^{\text {nd }}$ ed. New York: Macmillan.

Manning, Alan. 2003. Monopsony in Motion. Princeton: Princeton University Press. Marsden, David. 1999. A Theory of Employment Systems. Oxford: Oxford University Press.

Marshall, Alfred. 1920. Principles of Economics, 8th ed. London: Macmillan.

Medema, Steven. 1996. "Ronald Coase and American Institutionalism.” In Research in the History of Economic Thought and Methodology, Vol. 14. Greenwich: JAI Press, pp. 51-92.

Mirowski, Philip. 1989. More Heat than Light: Economics as Social Physics, Physics as Nature’s Economics. Cambridge: Cambridge University Press.

Nelson, Richard, and Sidney Winter. 1982. An Evolutionary Theory of Economic Change. Cambridge: Harvard University Press. 
North, Douglas. 1984. “Transaction Costs, Institutions, and Economic History.” Journal of Institutional and Theoretical Economics Vol. 140 (March), pp. 7-17.

Parsons, Kenneth. 1950. “John R. Commons’ Point of View.” Reprinted in J. Commons, The Economics of Collective Action. Madison: University of Wisconsin Press, pp. 341-75.

Pearce, David. 1999. The MIT Dictionary of Modern Economics, $4^{\text {th }}$ ed. Cambridge: MIT Press.

Prasch, Robert. 2004. "How is Labor Distinct from Broccoli? Some Unique Characteristics of Labor and Their Importance for Economic Analysis and Policy.” In D. Champlin and J. Knoedler, eds., The Institutionalist Tradition in Labor Economics. Armonk: M.E. Sharpe, pp. 146-58.

Ramstad, Yngve. “A Pragmatist’s Quest for Holistic Knowledge: The Scientific Methodology of John R. Commons.” Journal of Economic Issues, Vol. 20 (December), pp. 1067-1105. . 1990. "The Institutionalism of John R. Commons: Theoretical Foundations of a Volitional Economics.” In W. Samuels, ed., Research in the History of Economic Thought and Methodology, Vol. 8. Greenwich: JAI Press, pp. 53-106. . 1995. “John R. Commons’ Puzzling Inconsequentiality as an Economic Theorist.” Journal of Economic Issues, Vol. 29 (December), pp. 991-1012. . 1996. “Is a Transaction a Transaction?” Journal of Economic Issues, Vol. 30 (June), pp. 413-25.

Reder, Melvin. 1958. “Wage Determination in Theory and Practice.” In Neil Chamberlain, Frank Pierson, and Theresa Wolfson, eds., A Decade of Industrial 
Relations Research, 1946-1956, pp. 64-99. Madison: Industrial Relations Research Association.

. 1982. “Chicago Economics: Permanence and Change.” Journal of Economic Literature, Vol. 20 (March), pp. 1-38.

Rees, Albert. 1993. “The Role of Fairness in Wage Determination.” Journal of Labor Economics, Vol. 11 (January, pt. 1), pp. 243-52.

Robinson, Joan. 1933. The Economics of Imperfect Competition. London: Macmillan. Robinson, Romney. 1978. “The Theory of Imperfect Competition Reconsidered.” Journal of Economic Issues, Vol. 12 (December), pp. 871-90.

Rutherford, Malcolm. 1983. “J.R. Commons’ Institutional Economics.” Journal of Economic Issues, Vol. 17 (September), pp. 721-44. . 2001. "Institutional Economics: Then and Now." Journal of Economic Perspectives, Vol. 15 (Summer), pp. 173-94.

Samuels, Warren. 1969. “On the Future of Institutional Economics.” Journal of Economic Issues, Vol. 3 (September), pp. 67-72. . 1997. “Instrumental Valuation.” In W. Samuels, S. Medema, and A. Schmid, eds., The Economy as a Process of Valuation. Lyme: Edward Elgar, pp. 1-71. , and A. Allan Schmid. 1997. “The Concept of Cost in Economics.” In W. Samuels, S. Medema, and A. Schmid, eds., The Economy as a Process of Valuation. Lyme: Edward Elgar, pp. 208-98. , and Steven Medema. 1997. "Ronald Coase on Economic Policy Analysis: Framework and Implications.” In S. Medema, ed., Coasean Economics” Law 
and Economics and the New Institutional Economics. Boston: Kluwer, pp. 161 $-84$.

Samuelson, Paul. 1947. Foundations of Economic Analysis. Cambridge: Harvard University Press.

Schmid, A. Allan. 1987. Property, Power \& Public Choice, $2^{\text {nd }}$ ed. New York: Praeger. . 2001. “The Institutional Economics of Nobel Prize Winners.” In J. Biddle, J. Davis, and S. Medema, eds., Economics Broadly Considered: Essays in Honor of Warren J. Samuels. New York: Routledge, pp. 281-311.

Skidelsky, Robert. 1992. John Maynard Keynes: The Economist as Savior, 1920-37, Vol. 2. New York: Penguin.

Slichter, Sumner. 1931. Modern Economic Society, $2^{\text {nd }}$ ed. New York: Henry Holt. Smelser, Neil, and Richard Swedberg. 2005. “Introducing Economic Sociology.” In N. Smelser and R. Swedberg, eds., The Handbook of Economic Sociology, $2^{\text {nd }}$ ed., pp. 3-25. New York: Russell Sage.

Smith, Adam. 1776. An Inquiry into the Nature and Causes of the Wealth of Nations, 1937 reprint. New York: Modern Library.

Solow, Robert. 1990. The Labor Market as a Social Institution. Cambridge: Basil Blackwell.

Soto, Hernando de. 2000. The Mystery of Capital: Why Capitalism Triumphs in the West and Fails Everywhere Else. New York: Basic Books.

Stigler, George. 1943. The Theory of Competitive Price. (Re-titled Theory of Price in the 1952 edition.). New York: Macmillan. 
Stiglitz, Joseph. 2000. "Democratic Development as the Fruits of Labor." Perspectives on Work, Vol. 4 (1), pp. 31-38.

Streeck, Wolfgang. 2005. “The Sociology of Labour Markets and Trade Unions.” In N. Smelser and R. Swedberg, eds., The Handbook of Economic Sociology, $2^{\text {nd }}$ ed., pp. 254-83. New York: Russell Sage. , and Kozo Yamamura. 2001. The Origins of Nonliberal Capitalism: German and Japan in Comparison. Ithaca: Cornell University Press.

Taylor, James. 1977. “Exploitation Through Contrived Dependence.” Journal of Economic Issues, Vol. 11 (March), 51-59.

Thurow, Lester. 1988. “Producer Economics.” In Proceedings of the Forty-First Annual Meeting, Industrial Relations Research Association. Madison: Industrial Relations Research Association, pp. 9-20.

Tymoigne, Éric. 2003. “Keynes and Commons on Money,” Journal of Economic Issues, Vol. 37 (September), p. 527-45.

Tool, Marc. 1991. “Contributions to an Institutional Theory of Price Determination.” In G. Hodgson and E. Screpanti, eds., Rethinking Economics: Markets, Technology and Evolution. Northampton: Edward Elgar, pp. 19-39.

Vanberg, Viktor. 1997. "Institutional Evolution through Purposeful Selection: The Constitutional Economics of John R. Commons,” Constitutional Political Economy, Vol. 8, pp. 105-22.

Veblen, Thorstein. 1898. “Why is Economics Not an Evolutionary Science?” Quarterly Journal of Economics (July), pp. 373-97. . 1899. Theory of the Leisure Class. New York: Modern Library. 
Walrás, Leon. 1874. Elements of Pure Economics (English translation, 1954).

Homewood: Irwin.

Weber, Roberto, and Robyn Dawes. 2005. “Behavioral Economics.” In N. Smelser and R. Swedberg, eds., The Handbook of Economic Sociology, pp. 90-108. New York: Russell Sage.

Whalen, Charles. 1989. “John R. Commons’s Institutional Economics: A ReExamination.” Journal of Economic Issues, Vol. 23 (June), pp. 443-54. . 1993. “Saving Capitalism by Making It Good: The Monetary Economics of John R. Commons.” Journal of Economic Issues, Vol. 27 (December), pp. 1155-79.

Williamson, Oliver. 1985. The Economic Institutions of Capitalism. New York: Free Press.

, Wachter, Michael, and Jeffrey Harris. 1975. "Understanding the Employment Relation” The Analysis of Idiosyncratic Exchange.” Bell Journal of Economics, Vol. 6 (Spring), pp. 250-78. 